are mentioned as accessory evidence in the above quotation, seem beside the point; indeed, they prompt doubts as to the soundness of the discussion and interpretation of the data, doubts which are strengthened by the description of the methods used for determining alleged periodicities in the small observed variations of the solar constant. This part of the text is taken substantially from Dr. Ábbot's paper of 1931, entitled "Weather Dominated by Solar Changes ", the main thesis of which has not carried conviction with most meteorologists. On this point, I am in agreement with Dr. Kimball, who, in the Monthly Weather Review (Dec. 1931, p. 479), wrote, " Is it rational to believe that these major weather changes are caused and explained by alleged short-period changes of less than 1 per cent on the intensity of solar radiation? A part, if not all, of this 1 per cent variation must be set off as caused by inevitable accidental errors, but even if the whole of it were real solar change, can we believe that if this small variation were to cease our major weather changes would disappear also?"
I would regret, however, to end this review on a critical note. The answer to doubts as to the solar variations will be afforded by observations which the Astrophysical Observatory is continuing, and by others for which it makes an earnest plea. While Dr. Abbot states that even the best present data, from Montezuma, fall just short of the accuracy that is required, he adds that there is good hope of making several improvements which should appreciably diminish the experimental error at all the stations.

Besides the main work relating to daily observations of the solar constant, the volume includes an account of the study of the distribution of radiation in the solar spectrum, particularly in the ultra-violet and infra-red regions not covered by the daily solar observations. One interesting and unlooked-for result of the Smithsonian work was the determination of the ozone content of the atmosphere above certain stations, from the yellow-green atmospheric transmission coefficients.

S. Chapman.

\title{
A Bibliography of Boyle
}

BIBLIOGRAPHY' is a word which has many meanings. The merely enumerative cataloguing of books is the least; their discrete anatomies a higher; and highest of all is their comparative anatomy, working on from detailed observation through steps of induction and verification as rigidly and delightfully scientific as any man of science could desire. But the aims of those who practise in these loftier realms are not always single. On one hand, the pure bibliographer has for his aim the discovery of bygone methods in the various crafts of book-making; to him the matter in the volumes which he studies is no more than the ' copy' supplied to a compositor, and the mind of the author-except inasmuch as its vagaries may cause disturbances in proof, and produce variant issues-exists as a remote First Cause, beyond inquiry. How much of the archæology of the greatest art in civilisation has been discovered by such students is recognised only vaguely, even by some of the historians who might make use of it. The literary bibliographer, on the other hand, has a different aim; his primary interest in a series of books is in their author (or a group of authors); yet even he wins little enough sympathy from most of us, who are content with the innocent rôle of gentle reader.

It will be seen that the bibliographer is a lonely soul as a rule; and if he strays beyond the warmth of his own eircle, the wind of the world blows past him chilly and comfortless. No wonder that he and his kind have hitherto purposely shunned contact with students of the impersonal arts of Nature, who outside their circle are supposed to be inhumanly heedless of persons and the past, and regardful only of things and the present. There have been, nevertheless, bibliographies (in the full sense) of scientific work : usually, however, according to subjects-such as Mr. James Henderson's
"Bibliotheca Taqularum Mathematicarum"-or of a library, such as Ferguson's well-known work on the Young chemical collection. Of bibliographies of single scientific authors there must hitherto have been very few that would satisfy bookmen as well as men of science. However, the collector's enthusiasm of the late Sir William Osler for medical works set a vogue in this field, and so it was not surprising that William Harvey was the subject of the first true bibliography of a seventeenth century scientific worker, produced a few years ago by Mr. G. L. Keynes. Now a kindred interest has inspired Prof. J. F. Fulton, lately fellow of Magdalen College, Oxford, and now professor in the School of Medicine at Yale, to undertake a larger and very difficult task: the bibliography of Robert Boyle.*

Let it be said at once that Prof. Fulton has carried out the task with particular success, happily conjoining the functions of both types of bibliographer. He has not only used the resources of a score or so of great libraries in Great Britain and on the Continent, but he has also achieved the rare privilege of being himself the owner of at least one copy of very nearly every work, edition, issue, and variant that comes within the wide scope of his title. The unrestricted opportunities for close examination and repeated reading which this has given him show, by their results in this volume, the honourable side of book-collecting; and the scientific historian (or, more probably, the group of them) who may some day try to set before us Boyle's contributions to knowledge, will be deeply in Prof. Fulton's debt.

In Section $A$ are described forty-two distinct and self-contained works by Boyle, first printed between

* Proceedings and Papers of the Oxford Bibliographical Society, vol. 3 , pt. 1, pp. 1-172. "A Bibliography of the Honourable Robert Boyle, Fellow of the Royal Society", by J. F. Fulton. (Oxford: University Press.) 108 . 
1659 and 1695 , and afterwards in editions and issues described to the number of about two hundred. This constitutes the most important part of the bibliography. In Section B are cited forty contributions by Boyle to other works, including thirty-five papers printed by the secretary of the Royal Society in the Philosophical Transactions. A third section shows the editions of Boyle's collected works, including the separate theological collections; there follow ten examples of bookdedications to him, contemporary and later; ten elegies and funeral sermons ; and notices of about a hundred and seventy biographies and commentaries on Boyle. An appendix contains a list of the Boyle's Lecture sermons and their preachers from 1692 to 1929 , and a list of the Robert Boyle lectures which have been given at Oxford for the last forty years. The frontispiece shows the attractive bust of Boyle by Rysbrack, discovered lately at Kensington Palace by Mrs. Esdaile; and there are twenty-two facsimile reproductions of titlepages and other matter. Prof. Fulton's preface is pleasant and useful, and there is a full index.

Each separate work is introduced by a short account of its bearing upon Boyle's life and upon the parts of science which it touches together with notes of general bibliographical interest. For each volume described, there are given the full title, with indications of the types used; the collation; any sub-title; notes of relationship to other issues; any special points; and a list of places where copies exist. As to the thoroughness of the book-anatomy, the reviewer can only say that he had a few small discoveries in this field which he thought were his own-but they are all here, and many more, and his chagrin as a censor is replaced by pleasure as a pupil. Prof. Fulton's assessments of Boyle's works do not profess to be more than finger-posts, and ultimately the hoped-for scientific historian of Boyle might here and there dissent from a judg. ment. But, subject to this merely occasional reflection, Prof. Fulton's prefaces really add to the worth and interest of the book.

The Oxford Bibliographical Society is to be congratulated on having produced as part of its Pro. ceedings a handsome bibliography which is not only new in theme and long-wanted, but also as nearly final and complete as even, perhaps, its author could desire. To his modest terminal quotation from one of Boyle's prefaces, disclaiming the world's applause, one may be allowed to reply with one from another author; Dr. Fulton's is a work "In which, though to the blind and common crowde (to whom all thats unusuall is a paradox) there may perhapps appeare what they'll dare call extra. vagant, and to the midle-cyzed gymnastickes what they'll conceive ill grownded though ingenious guesses, yet surely will the more solide reflections of all knowing men begette a liking of its acquaintance".

IRVINE Masson.

\section{Amalgamation of the Physical and Optical Societies}

FTER full consideration of the scientific, legal, A financial, and political questions involved, a scheme for the amalgamation of the Physical Society of London and the Optical Society has been drawn up and unanimously recommended by a Committee representative of the two Societies. The process is now complete, and a new society, the Physical Society, has come into existence.

In pressing forward the scheme to completion, the Councils of these Societies were gratified to find that they had the support of an overwhelming majority of the members of both Societies, who fully realised that, despite the grave nature of the change involved, the advantages attendant thereon completely justified the action of the Councils.

It must be understood that the scheme is, as it states, an amalgamation-a fusion of the Societies concerned. The preservation of the name of a society is a matter which has, at best, a sentimental value; the conservation and widening of the advantages of membership is the material concern. In making a balanced estimate of the advantages accruing from such a fusion, it must be remembered that the circumstances in which the Optical Society was founded are scarcely germane to the present situation. However specialised its aims may have been in the earliest years of its existence, the Optical Society, as a glance at its Transactions will show, has developed into a general scientific body with an outlook scarcely to be distinguished from that of the Physical Society of London.

Thirty or forty years ago, in the homely days of the Victorian era, there was room, and need, for small semi-private societies, the members of which might meet and discuss in a familiar and intimate way problems of fundamental interest in their science and profession. Matters are changed nowadays. Physical science is playing a part in the fashioning of national character and the fostering of national well-being which was undreamt of a generation ago: scientific bodies are in far closer touch with the organised activities of the com. munity than they have ever been in the past, and unnecessary divisions and separations are to be deprecated, inasmuch as they inevitably weaken the weight of any appeal which may be made by the societies in the name of physical science. There is no question that the prestige and authority of the Society which has risen from the union of the two Societies will far exceed that of the individual Societies considered as separate units.

The amazing growth of physical science during the past generation has inevitably produced much specialism. So far from taking all knowledge for his province, the scientific man of to-day is fortunate if he can cultivate with a measure of success some one corner of one of the sciences. Nevertheless, the repercussions of physical science in general on that single division are so numerous and so important that the neglect of their study unduly hampers the serious student. It has been an important part of the business of the Physical Society of London to make possible a critical study of these repercussions; the lectures and discussions which

No. 3283 , VoL. 130] 